\title{
The Xylanolytic System of Claviceps purpurea: Cytological Evidence for Secretion of Xylanases in Infected Rye Tissue and Molecular Characterization of Two Xylanase Genes
}

\author{
Sabine Giesbert, Heinz-Bernd Lepping, Klaus B. Tenberge, and Paul Tudzynski
}

Westf. Wilhelms-Universität, Institut für Botanik, Schloßgarten 3, D-48149 Münster, Germany.

Accepted for publication 30 June 1998.

\begin{abstract}
Giesbert, S., Lepping, H.-B., Tenberge, K. B., and Tudzynski, P. 1998. The xylanolytic system of Claviceps purpurea: Cytological evidence for secretion of xylanases in infected rye tissue and molecular characterization of two xylanase genes. Phytopathology 88:1020-1030.

Claviceps purpurea is a common phytopathogenic fungus that colonizes ovarian tissue of grasses. A concerted approach involving cytological and molecular techniques was initiated to investigate the role of the fungus' xylanolytic system in the interaction. Using enzyme-gold and immunogold electron-microscopic techniques, the presence of arabinoxylans in cell walls of rye ovarian tissues (i.e., along the usual path of infection of $C$. purpurea) was confirmed; tissue-print and immunostaining analyses indicated the presence of xylanase(s) exclusively in ovaries infected with $C$.

probes. cpxyll of $C$. purpurea had an open reading frame (ORF) of $832 \mathrm{bp}$ interrupted by a 181-bp intron. The derived gene product (CPXYL1) had a molecular mass of $21.5 \mathrm{kDa}$ and an $\mathrm{pI}$ of 8.88 ; it showed significant homology to family $\mathrm{G}$ endo- $\beta-1,4$-xylanases. The cpxyl2 ORF (1,144 bp) contained two introns (76 and $90 \mathrm{bp}$ ) and coded for a polypeptide of $33.8 \mathrm{kDa}$ with an $\mathrm{pI}$ of 7.01; CPXYL2 belonged to family $\mathrm{F}$ xylanases. Southern analyses with genomic DNA demonstrated that both genes were single-copy genes. Using reverse transcription polymerase chain reaction, it could be shown that both genes were expressed in vitro and in planta (during all infection stages). Inactivation of cpxyll was achieved by a genereplacement approach. The mutant strain $(\Delta$ cpxyll) had significantly reduced xylanase activity; Western analyses confirmed that it lacked a polypeptide of approximately $23 \mathrm{kDa}$.
\end{abstract} purpurea. This strongly suggests that $C$. purpurea secretes xylanase while colonizing its host. Two xylanase genes (cpxyll and cpxyl2) were isolated from a genomic library of $C$. purpurea using genes from Cochliobolus carbonum (xyl1) and Magnaporthe grisea (xyn33) as heterologous
Additional keywords: cell wall-degrading enzymes, gene disruption, hostparasite interaction.
Claviceps purpurea (Fr.:Fr.) Tul. is a common flower pathogen of a wide range of grasses and cereals. Wind-borne ascospores, produced by sclerotia in spring, attach and germinate on the pistil surfaces of blooming host florets and initiate a specific pathogenesis pattern: within 1 week, hyphae invade and colonize the ovary, grow down to the tip of the ovary axis, and establish a specific, persisting, host-parasite frontier after having tapped the host vascular system. The highly organ-specific, biotrophic fungus never invades any part further down in the host, but proliferates above this site. A sphacelial stroma grows profusely in the ovary, producing masses of anamorphic spores that are exuded into a syrupy fluid. With this honeydew, the conidiospores are transferred to other florets. Thereby, $C$. purpurea spreads spatially in the field having used the plant gynoecia for its own proliferation. Next, honeydew production and conidiation usually cease when the formation of sclerotia starts. Sclerotia mature in about 5 weeks and typically contain ergot alkaloids. Finally, during autumn, instead of a kernel, a ripe sclerotium leaves the spike, making ergot a replacement-tissue disease. The hard compact ergot consists of special storage cells and a typically pigmented outer cortex. It serves for sexual reproduction and as a resting structure to survive unfavorable conditions.

During the initial colonization process, the fungus grows intraand intercellularly, as it is able to penetrate (and completely dissolve) the host's cell walls $(37,40)$. In accordance with its overall biotrophic mode of growth, $C$. purpurea secretes only limited amounts of hydrolytic enzymes in axenic culture. Among the few

Corresponding author: P. Tudzynski; E-mail address: tudzyns@uni-muenster.de

Publication no. P-1998-0819-01R

(c) 1998 The American Phytopathological Society enzymatic activities detected until now are pectinases (31), a $\beta-1,3-$ glucanase (6), and at least two xylanases (S. Giesbert, unpublished data). To elucidate the role of extracellular hydrolytic enzymes during the colonization of host tissue by $C$. purpurea, we initiated an integrated molecular approach that encompasses target studies (identification of cell wall polymers degraded during the interaction), cloning and characterization of genes coding for cell wall-degrading enzymes (CWDEs), expression studies (via reverse transcription polymerase chain reaction [RT-PCR], in situ hybridization, and immunogold electron-microscopic [EM] analyses), and targeted gene disruption. We demonstrated that cellulose is efficiently degraded in host cell walls that are in contact with fungal hyphae, and we cloned and characterized a gene (cell), probably coding for a cellobiohydrolase (lacking a substrate-binding domain), that is only expressed during the first days postinfection (28). During intracellular growth, the fungus efficiently degrades pectin/pectate. We cloned two closely linked putative endo-polygalacturonase genes that are expressed throughout the entire infection process (37). Functional analyses of the role these genes play during colonization of host tissues are under way, including creation of deletion mutants.

It has been reported that cell walls of grass leaves consist of approximately $40 \%$ glucuronoarabinoxylans (GAX) (8). Evidence for the presence of both $\beta-1,4$-xylan and arabinose side groups in cell walls of rye ovarian tissue, attained using enzyme-gold and immunogold techniques, is presented here for the first time. These data indicate that especially xylanases, as well as pectinases and cellulases, are important for the weakening of the host cell walls prior to penetration. As a basis for functional in planta studies, we cloned and characterized two putative xylanase genes, studied their expression and secretion both in planta and in axenic culture, and successfully inactivated one of them by a gene-replacement approach. 


\section{MATERIALS AND METHODS}

Strains and culture conditions. A standard field isolate of $C$. purpurea, strain T5 isolated from rye (Secale cereale L.) in Hohenheim, Germany (13), and a haploid derivative strain 20.1 obtained after benomyl treatment (27) were used for all studies. Mycelia were cultivated in $100 \mathrm{ml}$ of complete medium BII (14) and modified complete medium according to Mantle and Nisbet (26) with reduced sugar content (Mantle B: 1\% [wt/vol] glucose) in $300-\mathrm{ml}$ Erlenmeyer flasks at $28^{\circ} \mathrm{C}$ on a rotary shaker at $150 \mathrm{rpm}$ or for 14 days on solid medium plates containing $1.5 \%$ (wt/vol) agar. Escherichia coli DH5 $\alpha$ (18) was used routinely for cloning and propagation of plasmids. $\lambda$ clones were propagated in $E$. coli strain K 803 (45).

Parasitic culture on rye plants. Rye plants were cultivated in growth chambers as described by Smit and Tudzynski (34) and inoculated with conidia from axenic cultures of $C$. purpurea as described elsewhere (37). Inoculated florets of defined infection stages of ergot were used together with corresponding noninoculated controls. The selected stages depicted in Müller et al. (28) were as follows: infected ovaries before honeydew production, 1 to 7 days postinoculation (dpi); young sphacelia with honeydew production, 8 to $10 \mathrm{dpi}$; old sphacelia, about $15 \mathrm{dpi}$; and young sclerotia, about $20 \mathrm{dpi}$.

Transmission electron microscopy (TEM) and affinity-gold cytochemistry. For the processing of specimens for on-grid labeling, whole pistils including axes were excised from rye florets. They were fixed in sectioned parts of appropriate size for $1.5 \mathrm{~h}$ at room temperature in a mixture of $4 \%$ (wt/vol) formaldehyde generated from paraformaldehyde (E. Merck AG, Darmstadt, Germany) and $1 \%$ (vol/vol) glutaraldehyde in $25 \mathrm{mM}$ sodium phosphate buffer, $\mathrm{pH}$ 7.0. Further processing of the nonosmicated samples via dehydration in ethanol, embedding in London resin white (TAAB Laboratories, Munich) at $60^{\circ} \mathrm{C}$, ultramicrotomy with diamond knifes, handling of nickel grids, and washing steps during labeling and electron microscopy was performed as previously described (36). The various labeling experiments were repeated several times, each with at least two grids carrying at least two sections and with additional control grids.

For immunogold localization of terminal arabinofuranosyl residues in arabinoxylan, previously described protocols were modified $(1,37)$. Sections were treated for $30 \mathrm{~min}$ with normal goat serum diluted 1:100 in $150 \mathrm{mM}$ phosphate-buffered saline (PBS), $\mathrm{pH} 7.4$, containing $0.2 \%$ (wt/vol) gelatin and $50 \mathrm{mM}$ glycine. They were incubated with a monoclonal antibody (MAb) from mouse, an $\alpha$ L-arabinofuranose-specific immunoglobulin G (IgG) (Biosupplies Australia, Parkville, Victoria, Australia), diluted 1:10 in PBS containing $0.5 \%$ (wt/vol) bovine serum albumin (BSA) (Sigma-Aldrich, Deisenhofen, Germany) for $14 \mathrm{~h}$ at $4^{\circ} \mathrm{C}$. Grids were treated for $45 \mathrm{~min}$ at room temperature with goat anti-mouse $\mathrm{IgG}+\operatorname{IgM}$ linked to $20 \mathrm{~nm}$ of colloidal gold particles (EM.GAF20; BioCell Research Laboratories, Cardiff, England) diluted 1:30 in PBS plus $0.5 \%$ (wt/vol) BSA. Controls for labeling specificity were run as a parallel set of sections incubated either with an inappropriate MAb, without a primary MAb, or with an anti- $\alpha$-L-arabinofuranosyl solution immuneprecipitated with a corresponding antigen, $1 \mathrm{mg}$ of arabinoxylan (Sigma-Aldrich) per $\mathrm{ml}$ or $1 \mathrm{mg}$ of pectin from citrus (Sigma-Aldrich) per $\mathrm{ml}$, for $17 \mathrm{~h}$ at $4^{\circ} \mathrm{C}$ before section treatment. Sections were treated with $2 \%(\mathrm{wt} / \mathrm{vol})$ periodic acid to alter glycosyl epitopes by oxidation.

For enzyme-gold localization of $\beta-1,4-x y l a n$, an endo- $\beta-1,4-D-$ xylan-xylano-hydrolase (EC 3.2.1.8) purified from Trichoderma viride (Sigma-Aldrich) was linked to colloidal gold according to a previously described protocol (35). Colloidal gold sol was prepared by adding $2 \mathrm{ml}$ of $1 \%$ (wt/vol) dihydrate sodium citrate and $0.45 \mathrm{ml}$ of $1 \%(\mathrm{wt} / \mathrm{vol})$ tannic acid to $100 \mathrm{ml}$ of $0.01 \%$ (wt/vol) tetrachloroauric acid (19) and adjusted to $\mathrm{pH}$ 5.5. The xylanase was dissolved in and dialyzed against double-distilled water. Eighty milligrams of xylanase per $\mathrm{ml}$ of gold sol was added, and the gold sol was further stabilized with $1 \%(\mathrm{wt} / \mathrm{vol}) \mathrm{BSA}$. After centrifugation at $17,000 \times g$ for $30 \mathrm{~min}$, the pellet was resuspended in double-distilled water, centrifuged again, and recovered in $50 \mathrm{mM}$ acetate buffer, $\mathrm{pH}$ 5.0. Before coating, the activity of the xylanase was tested in the xylanase assay, and the purity of the xylanase was verified by sodium dodecyl sulfate polyacrylamide gel electrophoresis (SDS-PAGE) and immunoblotting. For labeling of xylan, ultrathin sections were quenched for $15 \mathrm{~min}$ with $50 \mathrm{mM}$ acetate buffer, pH 5.0, containing 1\% BSA and $50 \mathrm{mM}$ glycine for $20 \mathrm{~min}$ and floated on xylanase-gold sol (1:100 diluted). Several labeling controls were performed including preincubation of the gold sol with 1\% (wt/vol) xylan (Sigma-Aldrich), 1\% (wt/vol) carboxymethyl-cellulose (Serva, Heidelberg, Germany), or the polyclonal anti-xylanase. Sections were treated with uncoated colloidal gold or nonenzymatic protein A-gold suspension.

Sections were contrasted with uranyl acetate and lead citrate and observed with a Siemens Elmiskop 102 electron microscope (Siemens AG, Berlin).

Tissue and mycelium printing. Immunomycelium and immunotissue blots were performed at room temperature, adapting tissueprinting protocols $(29,43)$. Whole mycelia grown for 2.5 , 5 , or 10 days on solid medium were used. Either infected or healthy ovaries were excised from the selected florets, rapidly plunge-frozen in liquid nitrogen, and divided longitudinally using a new razor blade in each case. The samples were placed on nitrocellulose membranes (0.45 $\mu \mathrm{m}$; Schleicher \& Schuell, Inc., Dassel, Germany) and pressed gently for up to $120 \mathrm{~s}$, carefully avoiding any displacement while printing. After short-washing with running double-distilled water, the membranes were treated for $1 \mathrm{~h}$ with $20 \mathrm{mM}$ Tris-HCl, $\mathrm{pH} 7.8$, containing 2\% (vol/vol) Tween 80 and $180 \mathrm{mM} \mathrm{NaCl}$ (TBS-Tween). They were incubated for $1 \mathrm{~h}$ in either the MAb anti-XYNI, the $\mathrm{MAb}$ anti-XYNII, or the polyclonal anti-xylanase anti-XYN, diluted 1:15,000 with TBS-Tween, and washed with running double-distilled water for 1 to $2 \mathrm{~min}$. Detection of immunoreactive peptides was achieved by incubation for $1 \mathrm{~h}$ in alkaline phosphatase linked to goat anti-mouse IgG and to goat anti-rabbit IgG, respectively, diluted 1:40,000 with TBS-Tween, mediating colorimetric reactions of naphtol AS-biphosphate and fast red-gg-salt (Sigma-Aldrich). Finally, the membranes were washed with running double-distilled water for $2 \mathrm{~min}$. Photographs were taken with a stereomicroscope Wild M3Z (Wild, Heerbrugg, Switzerland) using the camera device Wild-Leitz MPS52 (Leica, Bensheim, Germany) with Photoautomat MPS46 (Leica) and Kodak Ektachrome EPY 64T (Eastman-Kodak, Rochester, NY) film. In addition to the analyses of noninfected rye ovaries, control experiments were performed with primary antisera that were incubated with an excess of pure xylanase from $T$. viride (Sigma-Aldrich) prior to its use.

Protein techniques. To obtain protein extracts, the mycelium was separated from the culture fluid by filtration. Extracellular proteins were precipitated from the culture fluid by ammonium sulfate (90\% saturation), desalted by gel filtration (Sephadex G 25) in sodium-succinate buffer (0.05 M, pH 5.2), and concentrated with Centricon microconcentrators (Amicon, Heidelberg, Germany). Protein content was measured according to Bradford (5).

Xylanase activity was determined by a modification of the method described by Kombrink et al. (22) using 0.5\% xylan (oatspelts; Serva) in sodium-succinate buffer $(0.05 \mathrm{M}, \mathrm{pH} 5.2)$ as a substrate. SDS-PAGE was performed as described by Lämmli (24). Proteins were stained with Coomassie brilliant blue. Proteins separated by SDS-PAGE were electroblotted onto a Cellulosenitrate-Membrane (Schleicher \& Schuell, Inc.) and incubated in a solution containing MAbs raised in rabbit against $T$. reesei xylanase MAb anti-XYNI (23). The filter was afterwards treated with goat anti-mouse IgG (whole molecule; Sigma-Aldrich)-conjugated alkaline phosphatase. Cross-reacting proteins were visualized as described above.

Molecular genetic techniques. Standard molecular techniques such as cloning, gel electrophoresis, DNA and RNA blotting, la- 
beling of DNA, and DNA preparation from $E$. coli were performed according to Sambrook et al. (30) and Ausubel et al. (4). Isolation of genomic DNA from C. purpurea for Southern and PCR analyses was done as described by Cenis (9). For expression analysis,
RNA was prepared from infected ovaries collected at various stages according to Müller et al. (28). For expression analysis in axenic culture, RNA was extracted from mycelia grown on cellophane according to Chambers and Russo (10).

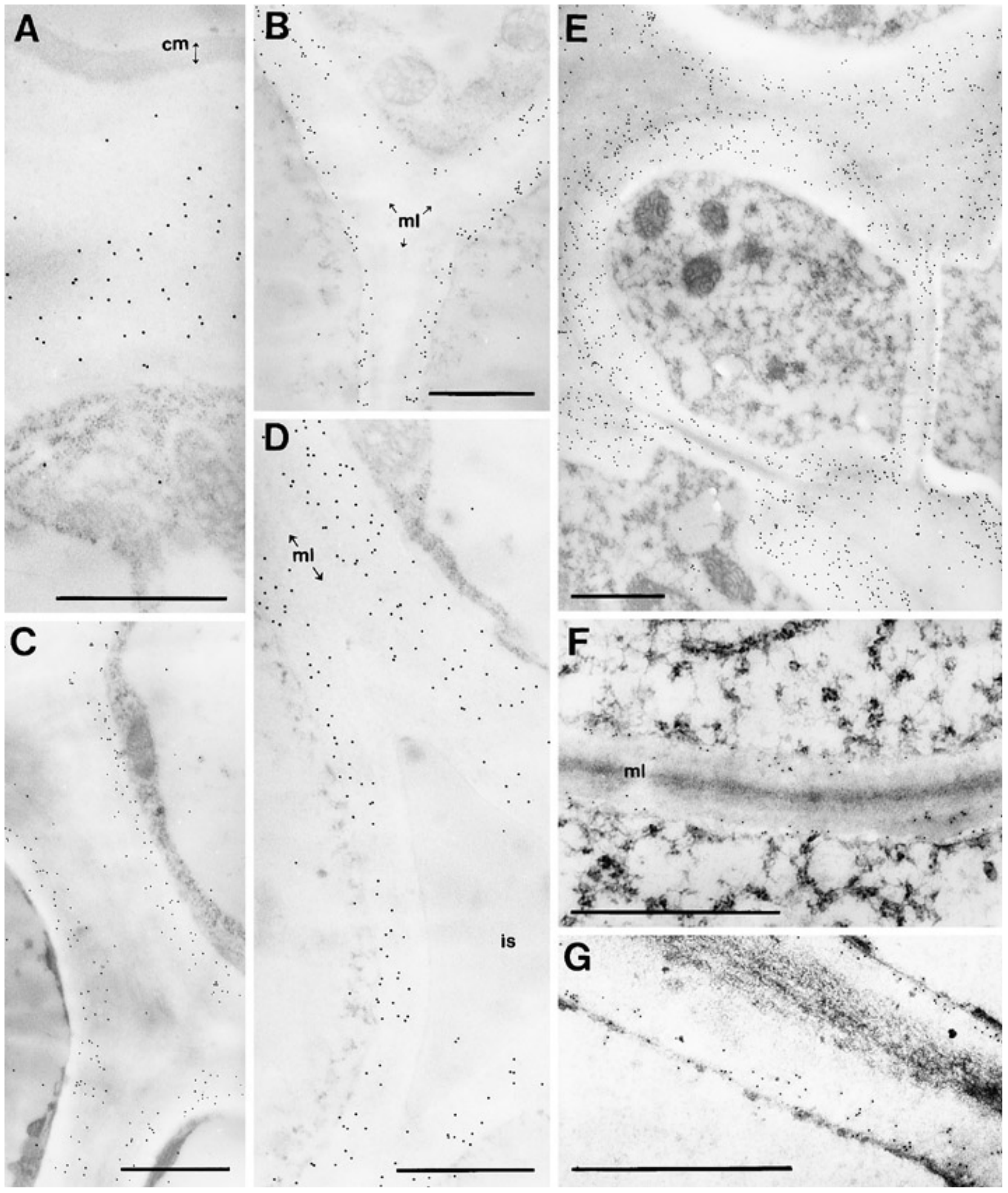

Fig. 1. Electron-microscopic localization of arabinoxylan in noninfected ovaries of rye. A to E, Enzyme-gold labeling of $\beta$-1,4-xylan with an endo-xylanasegold sol in cell walls of different ovary tissues as shown for $\mathbf{A}$, the outer epidermal wall; $\mathbf{B}$, a three-way junction of the carpel mesophyll; $\mathbf{C}$, thick-walled parenchyma; D, an intercellular space between young mesophyll cells; and E, a thick-walled cell with two pits in the rachilla cortical parenchyma. F and $\mathbf{G}$, Immunogold labeling with a monoclonal antibody specific for $\alpha$-L-arabinofuranosyl residues in xylan in cell walls of $\mathbf{F}$, the carpel mesophyll and $\mathbf{G}$, phloem elements. $\mathrm{cm}=$ Cuticular membrane, is = intercellular space, and $\mathrm{ml}=$ middle lamella zone. All samples were fixed in formaldehyde and glutaraldehyde, there was no osmication, samples were embedded in London resin white, and uranyl and lead salts were used for section staining. Scale bars $=1 \mu \mathrm{m}$. 


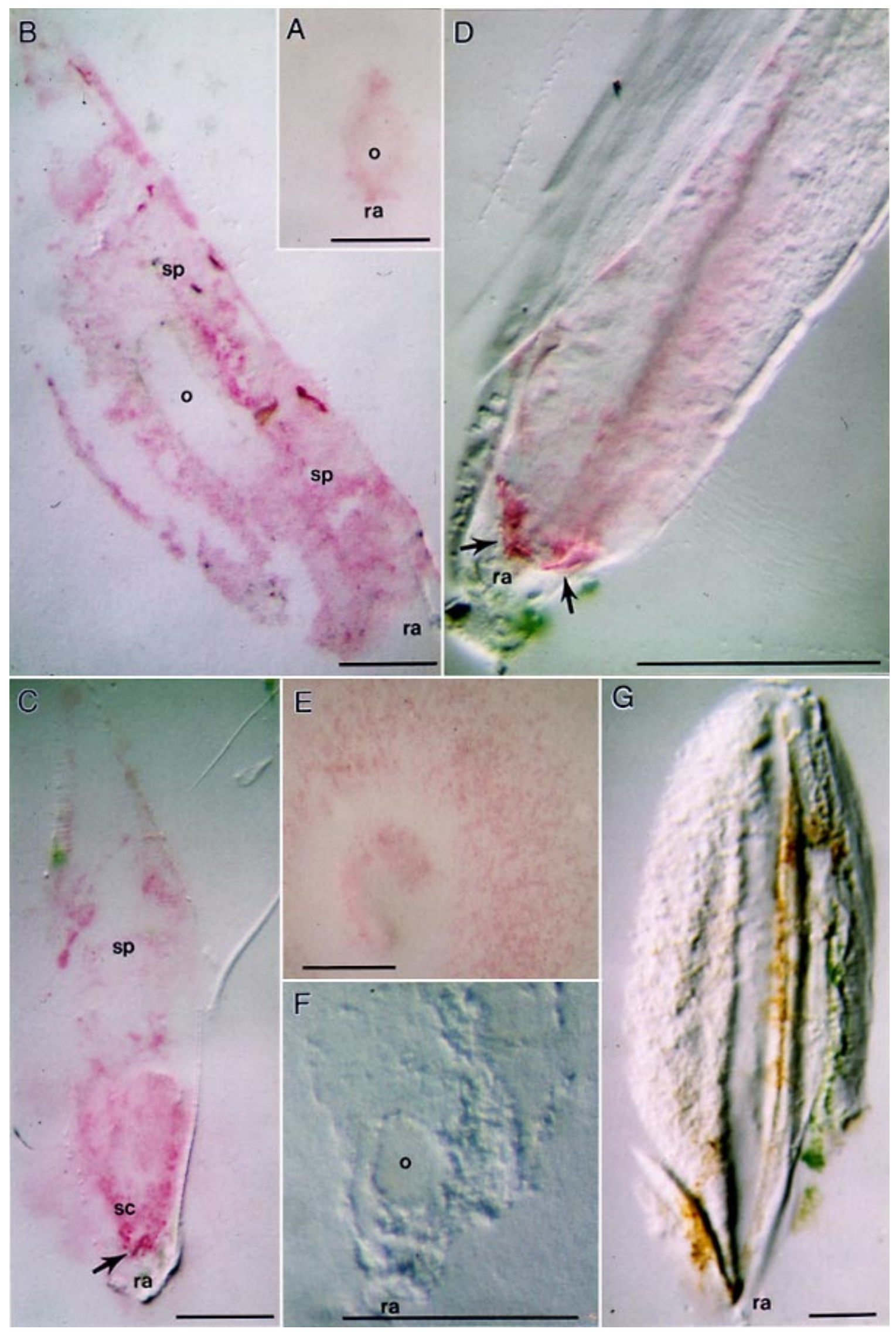

Fig. 2. A to D, In situ localization of xylanases using tissue printing and anti-XYNI-mediated immunostaining of infected rye ovaries inoculated with Claviceps purpurea T5a. Four progressive stages of ergot infection: A, young infected ovary before honeydew production, 4 days postinoculation (dpi); B, young honeydew producing sphacelium, 8 dpi; C, young sclerotium (sc) developing below an old sphacelium (sp), 16 dpi; and D, sclerotium, 28 dpi. E, In situ localization of xylanases using mycelium printing and anti-XYNI-mediated immunostaining of $C$. purpurea 20.1 after 5 days of axenic culture on solid medium with reduced sugar content. Tissue printing controls: $\mathbf{F}$, noninfected rye ovary at anthesis; and $\mathbf{G}$, young healthy caryopsis, 20 days postanthesis. $0=$ Ovule, ra $=$ rachilla, and arrows indicate the persistent host-pathogen boundary in the rachilla. Scale bars $=0.5 \mathrm{~mm}$. 
Screening of a genomic EMBL3 library of strain T5 (34) was performed by plaque filter hybridization according to Sambrook et al. (30). Nucleotide sequences of DNA fragments subcloned in pUC19 (48) or pBluescriptIISK- (33) were determined in an automated sequencer (LI-COR 4000; MWG, Ebersberg, Germany) using the Thermo Sequenase fluorescent-labeled cycle sequencing kit (Amersham International, Braunschweig, Germany). HUSAR (EMBL, Heidelberg, Germany) was used for computer analysis of DNA sequences.

RT-PCR was performed as described by Müller et al. (28); PCR analysis of transformants was done according to Sambrook et al. (30). Primers used for PCR analyses were XYL1a, 5' CAGGTACAGTTGTGGTGCC 3'; XYL1b, 5' GTCCCGAGCGGCATGCC 3'; XYL2a, 5' GGGTCAAGGCCATCAAG 3'; and XYL2b, 5' GTGGACGGGCCAGCCGGC 3'.

\section{RESULTS}

In situ localization of xylan in cell walls of ovary tissues of rye. To detect the presence of xylans within the polysaccharide network constituting the host cell walls, an endo- $\beta-1,4$-xylanase purified from $T$. viride was linked to a gold sol and characterized for its specificity and labeling properties in TEM. The xylan- degrading activity of the protein preparation was confirmed in a spectrophotometrical xylanase assay. SDS-PAGE revealed one single band that was immunoreactive with the MAb anti-XYNI in Western blotting experiments, confirming the purity of the xylanase preparation intended for the probing of xylan. All on-grid labeling controls verified the specificity of the xylanase-gold marker molecules for xylan localization; the preincubation of the enzymegold sol with a polyclonal xylanase antibody or with a potential xylan substrate reduced the labeling density to below that of the background level, while preincubation with carboxymethyl-cellulose had no effect (data not shown).

Treatment of healthy ovaries with the xylanase-gold sol resulted in a specific gold labeling of all cell walls in the different tissues along the usual infection path of the ergot fungus (Fig. 1). In outer epidermal cell walls, no labeling was found over the plant cuticle, while the labeling density increased towards the plant plasma membrane (Fig. 1A). Distinct gold label was present over the cell walls of young and elder mesophyll cells (Figs. 1B to D). In growing cell walls, the innermost wall layers facing the cytoplasm exhibited the highest labeling density. The middle lamella zone between two neighboring cells and the cell wall material that fills three-way cellular junctions (Fig. 1B and C) as well as the outer wall layer facing intercellular spaces (Fig. 1D) was free from xylanase-gold

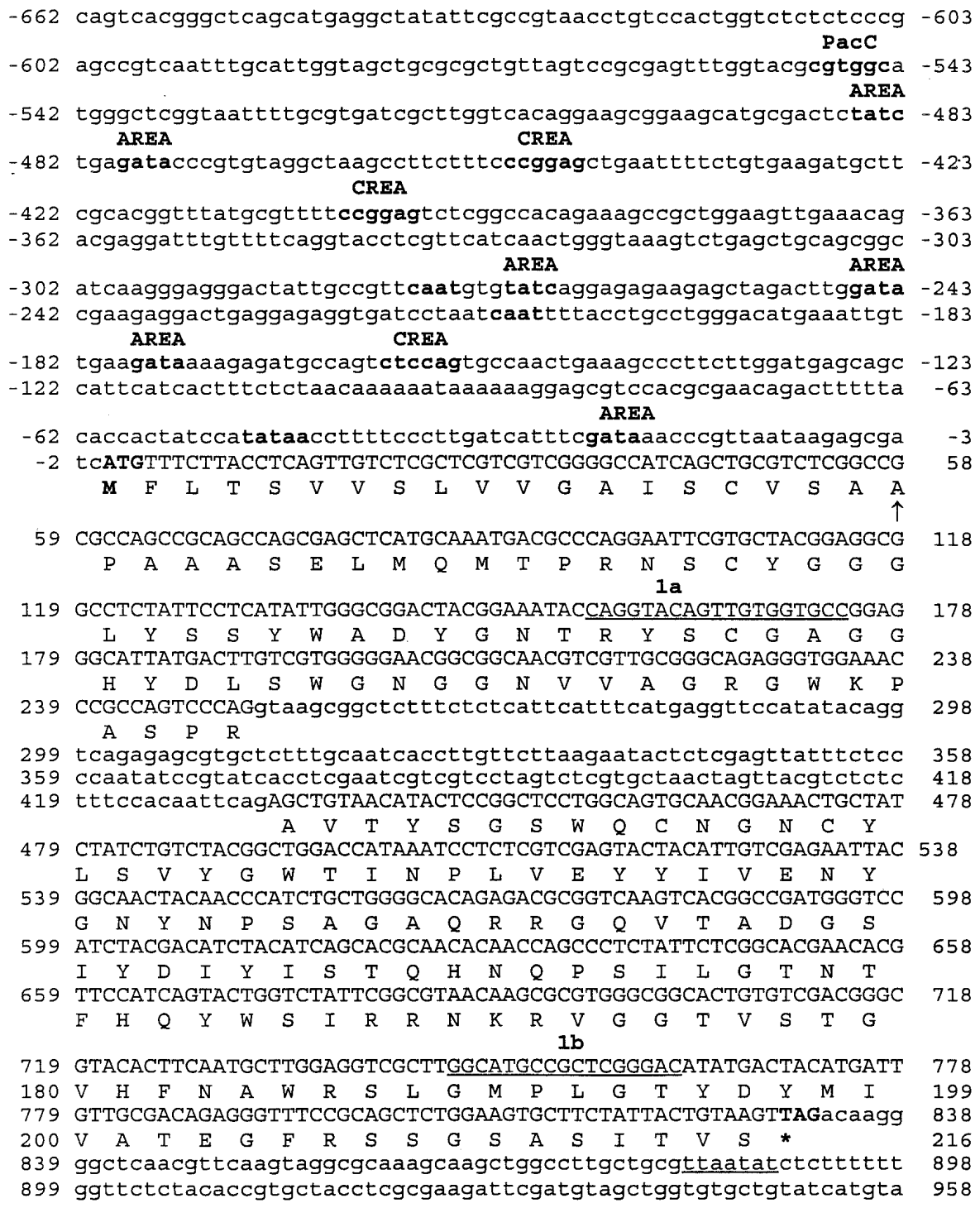

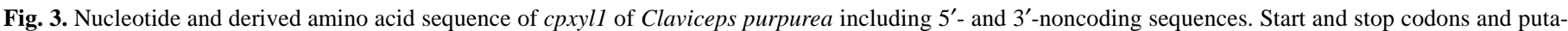

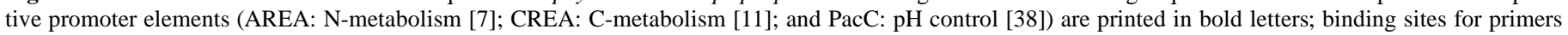

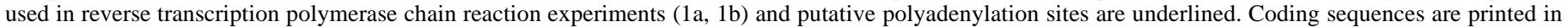
capital letters; the putative signal-peptidase cleavage site is indicated by an arrow. Accession number of $c p x y l 1$ : Y16969. 
particles. Especially strong labeling signals were detected over the wall thickenings of xylem tracheary elements and over secondary cell wall layers of the rachilla cortical parenchyma (Fig. 1E). These observations show that all the cell walls from different tissues contained sites that bound the gold-linked fungal xylanase, indicating the presence of $\beta-1,4$-xylan oligomers, the potential substrate of ergot xylanases.

To identify possible side groups linked to the $\beta$-1,4-xylan backbone, arabinose units were visualized in the polysaccharide network of the ovary wall with immunogold TEM and a MAb specific for terminal $\alpha$-L-arabinofuranosyl epitopes. Low but specific gold labeling was present in several different tissues of the ovary; the labeling was more intense in the region of the carpel mesophyll (Fig. 1F) and over the phloem elements (Fig. 1G) in the innermost cell wall layer facing the plasma membrane. No arabinosyl epitopes were detected in other cell wall regions. The labeling controls lacking primary antibody or treated with an antibody solution that was immunoprecipitated with arabinoxylan prior to application were devoid of gold particles, while preincubation of the antibody solution with pectin did not alter the labeling density (data not shown). The spatial pattern of the detected $\alpha$-L-arabinofuranosyl epitopes corresponded with that of the $\beta-1,4$-xylan epitopes detected in the enzyme-gold labeling, suggesting the occurrence of arabinoxylan in these wall layers.

Immunodetection of secreted xylanases in rye ovaries infected with $\boldsymbol{C}$. purpurea. For the analysis of the spatio-temporal secretion of xylanase in infected rye ovaries, three different heterologous anti-xylanase antibodies, one polyclonal antibody, and two MAbs (described in Material and Methods) were utilized in immunolocalization experiments. Western analysis after SDS-PAGE indicated that all three antibodies were immunoreactive with (at least) one xylanase of $C$. purpurea (described below). Immunogold labeling was not successful, neither after London resin white embedding nor with use of Lowicryl sections (Lowi, Chemische Werke GmbH, Waldkraiburg, Germany). This appeared to be due to a fixation-induced alteration of the epitopes, since aldehyde treatment was found to prevent the immunostaining of blots. Taking advantage of the immunoreactivity on blots, we adopted the immunoprinting technique to spatially localize the native proteins in relation to the physical imprints in nitrocellulose membranes. The experiments resulted in a positive staining for the presence of xylanases in all of the four major infection phases (Fig. 2). The red staining was visible throughout the colonized ovary wall. As is known from EM analysis (40), hyphae are regulatory scattered throughout the ovary wall mesophyll during the early colonization phase (Fig. 2A); the staining intensity increased in the subsequent sphacelial phase following the proliferation of the fungus in the host tissue (Fig. 2B). The typically noncolonized ovule zone did not stain (Fig. 2A and B). The young sclerotial plectenchyma, which develops intercalary between the fungal foot in the rachilla and the sphacelium, showed intensive staining, whereas the immunoreaction in the elderly sphacelium was only slight (Fig. 2C). Likewise, the staining intensity decreased while the sclerotium matured basipetally, and fully developed sclerotial hyphae gave no immunoreaction (Fig. 2D). Notably, at the persistent host-pathogen
C. purpurea

C. carbonum

T.reesei

A.nidulans

A.niger

H.insolens

T. harzianum

C. purpurea

C. carbonum

T.reesei

A.nidulans

A.niger

H.insolens

T. harzianum

C. purpurea

C. carbonum

T.reesei

A.nidulans

A.niger

H.insolens

T.harzianum

C.purpurea

C. carbonum

T.reesei

A.nidulans

A.niger

H.insolens

T.harzianum
-...--MFLTSVVSLVVGAISCVS - - - AAPAAASELMQMTPRNSCYGGGLYSSYWA MVSFTSIITAAVAATGALAAPATDVS - - - - - - - LVARQNTPNGEGTHNGCFWSWWS MVAFSSLICALTSIASTLAMPTGLEPESSVNVTERGMYDFVLGAHNDHRRRAS INYDQNY MVSFKSLLVLCCAALGAFATPVGSED - - - - LAAREASLLERSTPSSTGWSNGYYYSFWT -MLTKNLLLCFAAAKAALAVPHDSVAQ- - - RSDALHMLSERSTPSSTGENNGFYYSFWT MVSLKSVLAAATAVSSAIAAPFDFVP - - - -RDNSTALQARQVTPNAEGWHNGYFYSWWS (2.

120

D-YGNTRYSCGAGGHYDLSWGNGGNVVAGRGWKPASP -RAVTYSGSWQCN-GNCYLSVYG DGGARATYTNGAGGSYSVSWGSGGNLVGGKGWNPGTA-RTITYSGTYNYN-GNSYLAVYG QTGGQVSYSPSNTG-FSVNWNTQDDFVVGVGWTTGSS-APINFGGSFSVNSGTGLLSVYG DGGGDVTYTNGAGGSYTVQWSNVGNFVGGKGWNPGST-RTINYGGSFNPS-GNGYLAVYG DGGGDVTYTNGDAGAYTVEWSNVGNFVGGKGWNPGSA-QDITYSGTFTPS-GNGYLSVYG DGGGQVQYTNLEGSRYQVRWRNTGNFVGGKGWNPGTG-RTINYGGYFNPQ-GNGYLAVYG DGHAGVTYTNGGGGSFTVNWSNSGNFVGGKGWQPGTKNKVINFSGSYNPN-GNSYLSIYG *. . . * * *** . ..* * . * . **

180

WTINPLVEYYIVENYGNYNPSAGAQRRGQVTADGS IYDIYISTQHNQPS ILGTNTFHQYW WTRNPLVEYYVVENFGTYDPSSQSQNKGTVTSDGSSYKIAQSTRTNQPS IDGTRTFQQYW WSTNPLVEYYIMEDNHNYP - -AQGTVKGTVTSDGATYTIWENTRVNEPS IQGTATFNQY I WTQNPLIEYYIVESYGTYNPGSGGQHRGTVYSDGATYDIYTATRYNAPS IEGTATFEQFW WTTDPLIEYYIVESYGDYNPGSGGTYKGTVTSDGSVYDIYTATRTNAAS IQGTATFTQYW WTRNPLVEYYVIESYGTYNPGSQAQYKGTFYTDGDQYDIFVSTRYNQPS IDGTRTFQQYW WSRNPLIEYYIVENFGTYNPSTGATKLGEVTSDGSVYDIYRTQRVNQPSIIGTATFYQYW *. $* * * * \ldots *$ *.$\quad *$ * * * * . * *******.

234

SIRRNKRVGGTVSTGVHFNAWRSLGMPLGTYDYMIVATEGFRSSGSASITVS - SVRQNKRSSGSVNMKTHFDAWASKGMNLGQHYYQIVATEGYFSTGNAQITVNCP SVRNSPRTSGTVTVQNHFNAWASLGLHLGQMNYQVVAVEGWGGSGSASQSVSN SVRQSKRTGGTVTTANHFNAWAALGMRLGTHNYQIVATEGYQSSGSAS ITVY - SVRQNKRVGGTVTTSNHFNAWAKLGMNLGTHNYQIVATEGYQSSGSSSITVQ- SIRKNKRVGGSVNMQNHFNAWQQHGMPLGQHYYQVVATEGYQSSGESDIYVQTH SVRRNHRSSGSVNTANHFNAWASHGLTLGTMDYQIVAVEGYFSSGSASITVS-

* * * * * * * * * * * * * * * *

Fig. 4: Alignment of CPXYL1 to derived amino acid sequences of family G-type xylanase genes of Cochliobolus carbonum (xyl1 [2]), Trichoderma reesei (xynII [39]), Aspergillus nidulans (xyn2, P55333), A. niger (xynII [42]), Humicola insolens (xyl1 [12]), and T. harzianum (47). Residues identical in all polypeptides are marked by asterisks. Putative catalytic residues (E) are printed in bold letters. 
boundary in the host rachilla, a strong red staining for xylanases could be continuously detected and remained visible in the sclerotial phase (Fig. 2D, arrows). Tissue-printing experiments, carried out with healthy rye ovaries (Fig. 2F) and developing rye caryopses (Fig. 2G) as noninfected controls showed no immunoreaction, whereas tissue prints of axenically cultivated wild-type $C$. purpurea gave positive staining (Fig. 2E). The same was true for $T$. reesei cultures (data not shown). All three different antisera resulted in identical positive staining for xylanase on prints.

Cloning and characterization of two putative xylanase genes. Two different fungal xylanase genes were used as heterologous probes to isolate putative xylanase genes from a genomic EMBL3 library of $C$. purpurea strain T5: xyll from Cochliobolus carbonum, coding for a family G-type xylanase (2), and xyl2 from Magnaporthe grisea, coding for a family F-type xylanase (46). Both genes were first checked in Southern experiments for significant homology to genomic DNA of $C$. purpurea (data not shown).
From 50,000 plaques screened with the Cochliobolus carbonum probe, $21 \lambda$ clones were selected that showed strong homology to the probe (moderately stringent hybridization conditions). The homologous region was subcloned and sequenced; it was shown to contain an open reading frame (ORF) with significant homology to fungal xylanase genes and was named cpxyll. The cpxyll sequence comprised an ORF of 832 bp and was interrupted by an intron of $181 \mathrm{bp}$ (Fig. 3), the presence of which was confirmed by cDNA sequencing. Assuming that the first 19 amino acids probably represented a signal peptide, the derived gene product, CPXYL1, had an estimated molecular mass of $21.47 \mathrm{kDa}$ and a predicted $\mathrm{pI}$ of 8.88. The cpxyll sequence showed significant homology to other xylanases on both the nucleic acid and amino acid levels (e.g., $60 \%$ to Xyl1 from C. carbonum [2]). A comparison at the amino acid level (Fig. 4) indicated that cpxyll coded for a family G xylanase according to the classification of Gilkes et al. (16). Evaluation of the noncoding upstream sequence of cpxyll revealed typical

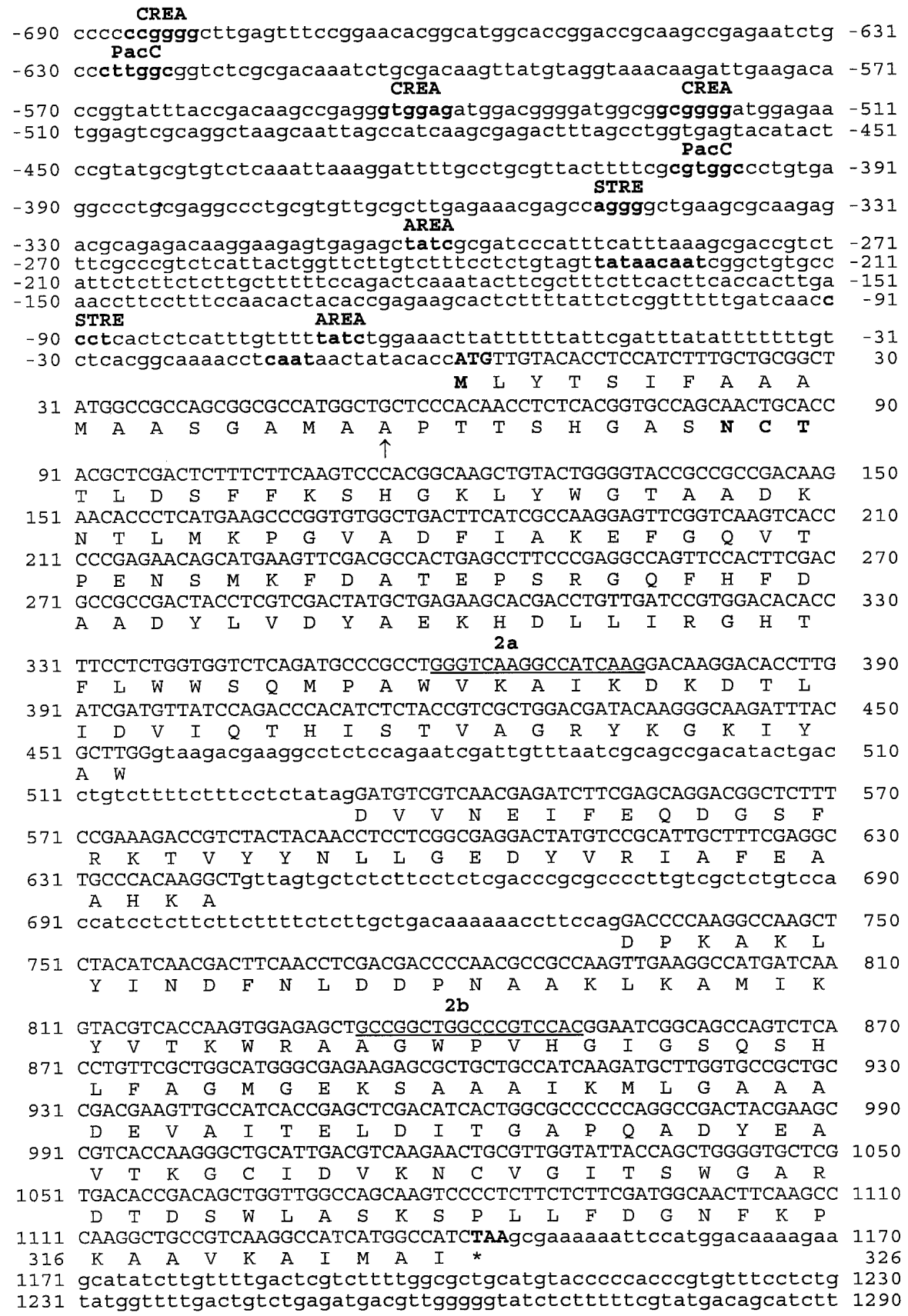

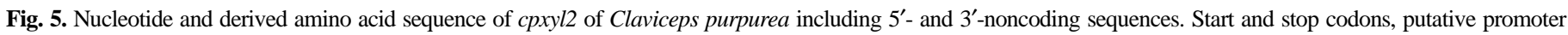

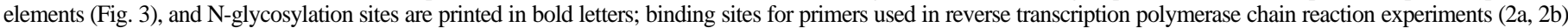
are underlined. Coding sequences are printed in capital letters; the putative signal-peptidase cleavage site is indicated by an arrow. Accession number of $c p x y l 2$ : Y16970. 
fungal promoter elements such as CT-rich regions, a TATAA box, and two CAAT boxes; the presence of several putative binding sites for CREA- and AREA-like transcription factors (Fig. 3) indicated that the expression of cpxyll might be regulated by the major $\mathrm{C}$ and $\mathrm{N}$ catabolite repression systems.

Using the $M$. grisea gene as a probe, 28 positive plaques were selected (from 50,000 screened). Subcloning and sequencing yielded a second putative xylanase gene termed cpxyl2 (Fig. 5). The gene had a coding sequence of $1,144 \mathrm{bp}$ that was interrupted by two introns of 76 and $90 \mathrm{bp}$ (confirmed by sequencing of cDNA clones). Assuming that here (as in cpxyll) the first 19 amino acids represented a signal peptide, the estimated gene product (CPXYL2) had an expected molecular mass of $33.8 \mathrm{kDa}$ and an $\mathrm{pI}$ of about 7.01. Comparison of the derived amino acid sequence showed significant homology to family $\mathrm{F}$ glycosyl hydrolases from Aspergillus awamori, Penicillium chrysogenum, and Fusarium oxysporum (Fig. 6), strongly suggesting that CPXYL2 was a family F xylanase. As in cpxyll, the promoter sequence of cpxyl2 contained several potential CREA and AREA binding sites; however, the large distance between the GATA-boxes made AREA control of this gene unlikely.

Southern analyses with genomic DNA of strain T5 showed that cpxyll and cpxyl2 were single-copy genes. The probes hybridized to one or two genomic fragments, depending on the enzyme used; as the bands hybridizing with the two probes were different, there was obviously no cross hybridization (data not shown).

Expression of cpxyl1 and cpxyl2 in axenic and parasitic culture. The expression of the two xylanase genes in axenic culture was subjected to Northern analysis. However, as had been the case with the cellulase and polygalacturonase genes of $C$. purpurea $(28,37)$, the signals obtained were very weak, indicating a low expression level of these genes under the tested conditions. Therefore, the far more sensitive method of RT-PCR was used. To differentiate between RNA-derived PCR products (426 and $326 \mathrm{bp}$ for cpxyll and cpxyl2, respectively) and (larger) PCR products caused by DNA contaminations (607 and 492 bp), primers spanning the intron-containing regions of both genes (Figs. 3 and 5) were used. We detected transcripts of both genes under all the conditions we tested in axenic culture (high/low $\mathrm{C}$ and $\mathrm{N}$ content, data not shown). As we were especially interested in the in planta expression of the genes, we performed RT-PCR for cpxyll and cpxyl2 using RNA from infected rye ovaries collected from all four infection stages (described above). The results are presented in Figure 7; both primer sets of PCR fragments of the expected sizes (426 and $326 \mathrm{bp}$ ) were detectable in all samples. As expected, the corresponding DNA controls yielded PCR fragments of 607 and $492 \mathrm{bp}$, respectively. Southern hybridization confirmed that the 426-bp PCR fragment was derived from cpxyll (Fig. 7A). The identity of the

\begin{abstract}
A. awamori
P. chrysogenum

F. oxysporum

c. purpurea
\end{abstract}

A. awamori

P. chrysogenum

F. oxysporum

c. purpurea

150

IGDQYTLTKN SKTPAVIKAD FGALTPENSM KWDATEPSRG QFSFSGSDYL IADQGTLNGN PKTPAIIKAN FGQLSPENSM KWDATEPSQG QFSFAGSDYF EIDHYHLNNN PLI.NIVKAQ FGQVTCENSM KWDAIEPSRN SFTFSNADKV AADKNTLMK. PGVADFIAKE FGQVTPENSM KFDATEPSRG QFHFDAADYL * * * * $* * * * * * * * * * * * *$

VNFAQSNNKL IRGHTLVWHS QLPSWVQAIT DKNTLIEVMK NHITTVMQHY VEFAETNGKL IRGHTLVWHS QLPSWVSSIT DKTTLTDVMK NHITTVMKQY VDFATQNGKL IRGHTLLWHS QLPQWVQNIN DRSTLTAVIE NHVKTMVTRY VDYAEKHDLL IRGHTFLWWS QMPAWVKAIK DKDTLIDVIQ THISTVAGRY * * * ********************

250

A. awamori

P. chrysogenum

F. oxysporum

c. purpurea

KGKIYAWDVV .NEIFNEDGS LRDSVFYKVI GDDYVRIAFE TARAADPNAK KGKLYAWDVV .NEIFEEDGT LRDSVFSRVL GEDFVRIAFE TAREADPEAK KGKILQWDVV NNEIFAEDGN LRDSVFSRVL GEDFVGIAFR AARAADPAAK KGKIYAWDVV . NEIFEQDGS FRKTVYYNLL GEDYVRIAFE AAHKADPKAK *** $* * * * * * * \quad * * * * * * * * * * * * *$

300

A. awamori

P. chrysogenum

F. oxysporum

LYINDYNLDS ASYPKLA.GM VSHVKKWIEA GIPIDGIGSQ THLSAGGG.. LYINDYNLDS ATSAKLQ.GM VSHVKKWIAA GVPIDGIGSQ THLGAGAG.. LYINDYNLDK SDYAKVTRGM VAHVNKWIAA GIPIDGIGSQ GHLAAPSGWN

c. purpurea LYINDFNLDD PNAAKL.KAM IKYVTKWRAA GWPVHGIGSQ SHLFAGMGEK

A. awamori
P. Chrysogenum
F. oxysporum
C. purpurea

A. awamori

P. chrysogenum

F. oxysporum

c. purpurea$$
\text { * }
$$

.

. AGISGALN ALAGAGTKEI AVTELDIAGA SSTDYVEVVE ACLDQPKCIG . AAASGALN ALASAGTEEV AVTELDIAGA TSTDYVDVVN ACLDQPKCVG PASGVPAALR ALAASDAKEI AITELDIAGA SANDYLTVMN ACLAVPKCVG SAAAIK.... . MLGAAADEV AITELDITGA PQADYEAVTK GCIDVKNCVG * ************ $*$

400

ITVWGVAD. . . PDSWRSSST PLLFDSNYNP KPAYTAIANA L...... ITVWGVAD.. . PDSWRADES PLLFDASYNP KEAY.NVSQL LSRQHAFDLY ITVWGVSD. . . KDSWRPGDN PLLYDSNYQP KAAFNALANA L....... ITSWGARD. . . TDSWLASKS PLLFDGNFKP KAAVKAIMAI *...... *************

414
A. awamori
P. chrysogenum
F. oxysporum
c. purpurea
............ . .
LKLGNLLLSR LHSD
$\ldots \ldots \ldots \ldots$
$\ldots \ldots \ldots \ldots$

Fig. 6. Alignment of derived amino acid sequences of family F-type glycosyl hydrolase genes of Aspergillus awamori (xynA [20]), Penicillium chrysogenum (xynA [17]), and Fusarium oxysporum (cellulase [32]) with CPXYL2. Residues identical in all four polypeptides are marked by asterisks. A glutamic acid residue that is probably involved in catalytic activity is printed in bold letters. 
cpxyl2 fragment (326 bp) was verified by cloning and sequencing of the PCR product. These data confirm that both genes were expressed throughout the entire infection process.

Targeted inactivation of cpxyl1. To explore the role of CPXYL1 during the infection process, a gene-replacement approach was used to inactivate the gene. As shown in Figure 8, the phleomycin resistance cassette from vector pAN8-1 was used to construct a disrupted gene version (vector $\mathrm{p} \Delta x y l l \mathrm{phleo}^{\mathrm{R}}$ ). The haploid derivative 20.1 of strain T5 (27) was transformed with the purified HindIII fragment of the vector containing the disrupted cpxyll copy. Phleomycin-resistant transformants were obtained at a frequency of about two transformants per $\mu \mathrm{g}$. The DNA of 38 transformants, obtained from single-spore cultures, was digested with HindIII and subjected to Southern analysis using the labeled cpxyll gene as a probe. Transformants that carry the disrupted gene version from $\mathrm{p} \Delta x y l l \mathrm{phleo}^{\mathrm{R}}$ as a result of a double-crossover event should contain a 9.7-kb HindIII fragment instead of the wild-type $6.3-\mathrm{kb}$ fragment that hybridizes to cpxyl1. As documented in Figure 9, the cpxyllhomologous band of one of the 38 transformants (X12) showed the expected shift in molecular weight. This homologous transformant was named $\Delta c p x y l 1-1$ and analyzed biochemically. Activity tests showed that it had a significantly reduced xylanase activity in axenic culture (Mantle B medium; strain 20.1: $133.3 \pm 5.8 \mu \mathrm{kat} / \mathrm{kg}$; transformant X12: $43.3 \pm 7.1 \mu \mathrm{kat} / \mathrm{kg}$ ), indicating that CPXYL1 was responsible for at least about $60 \%$ of the total xylanase activity under these conditions.

Using the cpxyll deletion strain it was possible to show that a $23-\mathrm{kDa}$ protein that showed a cross-reaction with MAbs (MAb
XynI) raised against the xylanase XynI from $T$. reesei was indeed the cpxyll gene product. As shown in Figure 10, the 23-kDa band (the only one detected by the heterologous antibodies) present in strain 20.1 is missing in strain $\Delta$ cpxyll-1, confirming both that this band represented CPXYL1 and that cpxyll was indeed disrupted in the transformant. Likewise, in contrast to experiments with the wild-type strain, mycelium printings of the mutant strain axenically cultured on solid plates gave no immunostaining with MAb XynI.

\section{DISCUSSION}

Cytological aspects. According to the model of plant cell wall architecture outlined by Carpita and Gibeaut (8), grasses possess a type II cell wall containing a high percentage of GAX. The cytological data presented here confirm this model for the first time for the ovarian tissue of Secale cereale; the enzyme-gold analyses clearly show the presence of an oligoxylan with $\beta$-1,4-linkages, and the immunogold labeling using a MAb indicates the presence of arabinofuranosyl side chain, although the reaction of the antibody with arabinosyl units linked to other polysaccharides such as arabinogalactan or pectin cannot be excluded. The diversity of the enzyme-gold and immunogold labeling suggests a complex, tissuespecific distribution of diversely structured arabinoxylans in the ovarian tissues of rye. These data clearly demonstrate the presence of xylans along the infection pathway of $C$. purpurea. Together with the complete degradation of host cell walls at the host-fungus interface $(40,27)$, this indicates that xylan-degrading enzymes are
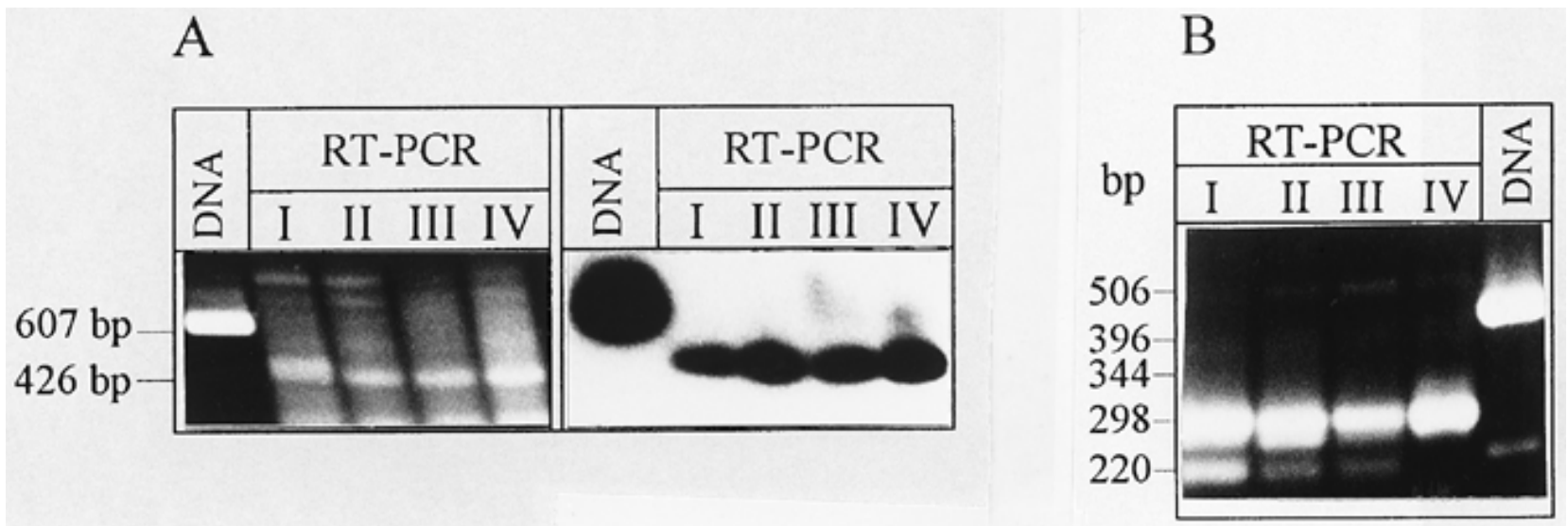

Fig. 7. Reverse transcription polymerase chain reaction (RT-PCR)-based expression analysis of cpxyll and cpxyl2 in planta. RNA from different infection stages and DNA (as a control) served as templates for the RT-PCR reaction. A, Primer 1b was used for reverse transcription and in combination with primer 1a for the amplification (Fig. 3). Expected sizes: 606 and 426 bp for the DNA- and RNA-derived products, respectively. Left, ethidium bromide-stained agarose gel; and right, Southern hybridization using cpxyll as a probe. B, RT-PCR products that were obtained using primers $2 \mathrm{~b}$ and $2 \mathrm{a}$ (Fig. 5); expected sizes: 491 and 324 bp. Identity of the PCR fragment was verified by sequence analysis.

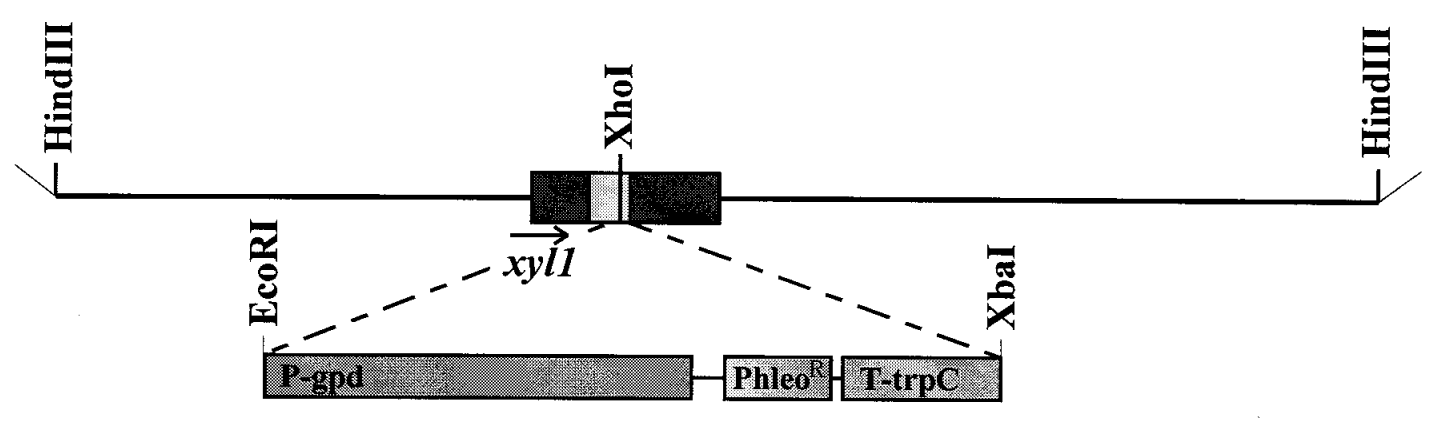

$0.5 \mathrm{~kb}$

Fig. 8. Construction of the $x y l 1$ gene-replacement vector $\mathrm{p} \Delta x y l l \mathrm{phleo}^{\mathrm{R}}$. Plasmid $\mathrm{pH} x y l 1$ that contains the $x y l 1$ gene of Claviceps purpurea was digested with XhoI. The EcoRI/XbaI phleomycin cassette (comprised of the Streptomyces verticillium phleomycin resistance gene phleo ${ }^{\mathrm{R}}$, the gpd promoter from Aspergillus niger and the A. niger terminator sequence trp ${ }^{\mathrm{C}}$ ) was cloned into the XhoI site of the xyll gene. For performing transformation experiments the HindIII fragment of $\mathrm{p} \Delta x y l l \mathrm{phleo}^{\mathrm{R}}$ was used. The $x y l l$ intron is represented by a lightly shaded box, noncoding sequences by narrow open bars. 
important for the colonization of the host tissue. The tissue-printing and immunostaining analyses present evidence for xylanase activity in ovaries infected with $C$. purpurea $(35,40)$, indicating that the fungus secretes xylanases in both saprophytic culture and infected tissue.

These indications of the importance of xylanases in the pathogenesis of $C$. purpurea were convincing enough to initiate a molecular characterization of the xylanolytic system including the cloning of xylanase genes, analysis of their expression, and the creation of deletion mutants that would serve as a basis for a functional analysis.

Structural aspects of cpxyl1 and cpxyl2. The endo-xylanases characterized until now have been grouped into the families $\mathrm{F}$ and $\mathrm{G}$ of glycosyl-hydrolases according to the classification of Gilkes et al. (16). As shown in Figures 4 and 6, the two putative xylanase genes isolated from a genomic library of $C$. purpurea by heterologous probing are obviously members of those groups: CPXYL1 shows significant homologies to glycosyl hydrolases of the $G$ family, CPXYL2 to those of family F. Accordingly, both genes (and the derived polypeptides) show no significant homology to each other. Both polypeptides contain the conserved residues characteristic of their family, e.g., CPXYL1: two glutamic acid residues (E112 and E203) of the catalytic center (21) and two tyrosine residues that are probably involved in substrate binding (Y103 and Y113) (44). Since the two enzymes have not yet been purified, it is not known if they have different substrate specificities.

The promoter sequences of both genes contain potential binding sites for (homologues of) the major regulatory proteins: AREA (7), CREA $(11,25)$, and PACC (38), indicating that these global regulators of $\mathrm{N}$ - and $\mathrm{C}$-metabolism and $\mathrm{pH}$ control, respectively, may be involved in the expression of cpxyll and cpxyl2.

Expression of cpxyl1 and cpxyl2. The RT-PCR experiments outlined above allowed detection of the transcripts of both genes in planta in all stages of infection, which correspond to the results from the tissue printings. These data do not allow conclusions about the level of gene expression in the different infection phases, but they are interesting when compared with RT-PCR data obtained with other CWDEs of $C$. purpurea $(27,37)$; transcripts of the cell gene (coding for a cellobiohydrolase) are detectable by RT-PCR only in stage I, and those of $p g 1$ and $p g 2$ (coding for polygalacturonases) are detectable only in stages I to III. In contrast, cpxyll and cpxyl2 are expressed in all stages, although detailed analyses such as quantitative PCR might show a phase-specific variation in their expression level. Immunolocalization using homologous antibodies raised against the purified $C$. purpurea xylanases and in situ hybridization experiments with specific gene probes will give a detailed view of the temporal and spatial distribution of the cpxyll and cpxyl 2 expression.

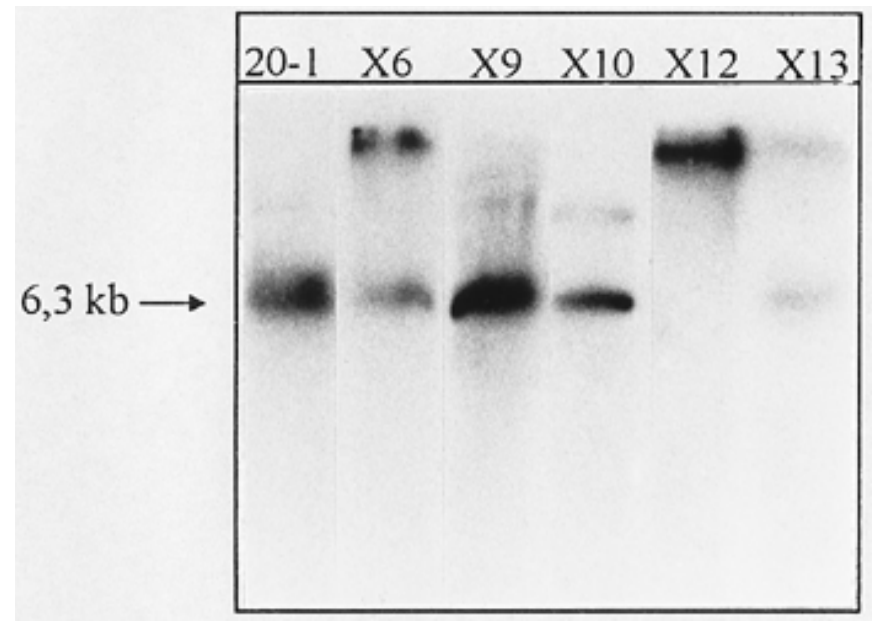

Fig. 9. Southern analysis of $\mathrm{p} \Delta x y l \mathrm{phleo}^{\mathrm{R}}$ transformants of strain 20.1 . Genomic DNA from Claviceps purpurea wild type (20.1) and the putative mutants were digested with HindIII, fractionated, blotted, and hybridized with the HindIII fragment of plasmid pHxyll (Fig. 8).
Functional aspects and perspectives. The presence of at least two xylanase genes in $C$. purpurea is not unique; several phytopathogenic fungi secrete more than one xylanase, e.g., Cochliobolus carbonum probably has at least four xylanase genes (3) and M. grisea six (46). This could be important for the efficient degradation of the complex group of natural xylans; the various enzymes could complement each other with respect to stability, $\mathrm{pH}$ optimum, and substrate specificity. Especially in pathogens of cereals and grasses (which have a type II cell wall with a high xylan content), this enzyme system could be very important in leading the initial attack on the host's cell wall, widening the pores, and rendering the other cell wall components (cellulose and pectin) more accessible to degrading enzymes. The technique of targeted gene inactivation methods enables the analysis of the specific function of the different enzymes. As of yet, dramatic effects resulting from the deletion of xylanase genes have not been reported (41). However, most cases lack a detailed cytological analysis, and most of the fungi that have been analyzed in this respect are necrotrophic. The situation might be quite different in a biotrophic fungus such as $C$. purpurea, which secretes only very limited amounts of CWDEs and must establish a stable interaction with its living host. Therefore, a functional analysis using a knock-out approach especially in combination with detailed cytological studies is feasible in C. purpurea, in spite of the negative results in other systems. We report here the deletion of cpxyll by a gene-replacement approach; the successful inactivation of the gene is documented by the loss of the wild-type genomic DNA fragment in Southern experiments, by the loss of a $23-\mathrm{kDa}$ protein cross-reacting with heterologous xylanase-specific antibodies, and by a significant reduction in overall xylanase activity in the mutant. This is only the third example for a successful targeted gene inactivation in $C$. purpurea, the others include a cellobiohydrolase gene, cpcell (27), and a catalase gene, cpcatl (15). In all these cases, we used a gene-replacement approach, which has the advantage over a genedisruption strategy that restoration of the locus via recombination is impossible. Knock-out mutants were obtained in all these systems at a frequency of about 1 to $3 \%$. Thus, the methods are now available for a detailed functional analysis of the xylanolytic system in the interaction of $C$. purpurea and rye. For this purpose, it will be necessary to construct cpxyl2 deletion mutants, cpxyll/ cpxyl2 double mutants, and mutant strains complemented with the corresponding wild-type genes and to monitor the effects of these

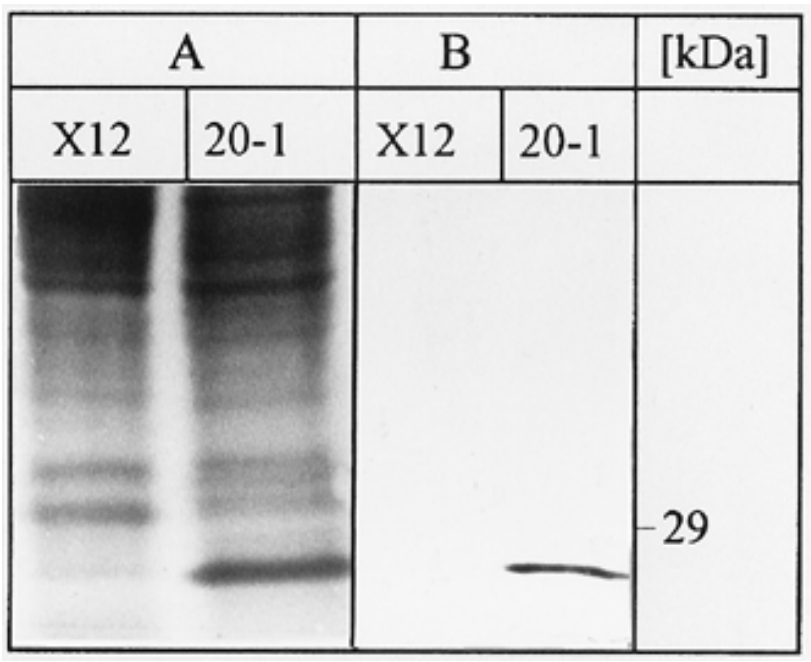

Fig. 10. Sodium dodecyl sulfate-polyacrylamide gel electrophoresis (SDSPAGE) and immunoblot analysis of proteins secreted by strain 20.1 and the $\Delta$ cpxyl1 mutant strain. A, Protein from culture filtrate of the wild-type strain (20.1) and the $\Delta$ cpxyll mutant (X12) were separated by SDS-PAGE and stained with Coomassie brilliant blue. B, Proteins were blotted onto a nitrocellulose membrane and stained with antibodies raised against Trichoderma reesei xylanase (monoclonal antibody XynI). 
deletions/complementations by cytological and biochemical analyses in vitro and in planta.

\section{ACKNOWLEDGMENTS}

This work was supported by the Deutsche Forschungsgemeinschaft (DFG, Bonn). We thank J. D. Walton (Michigan State University) and S. C. $\mathrm{Wu}$ (University of Georgia) for providing us with the xyll gene of Cochliobolus carbonum and the xyn33 gene of Magnaporthe grisea and antibody, respectively; C. Kubicek (Wien) for the generous gift of antisera; and S. Moore for reading and A. Kammerahl for typing the manuscript.

\section{LITERATURE CITED}

1. Anderson, M. A., Harris, P. J., Bonig, I., and Clarke, A. E. 1987. Immuno-gold localization of $\alpha$-L-arabinofuranosyl residues in pollen tubes of Nicotiana alata Link et Otto. Planta 171:438-442.

2. Apel, P. C., Panaccione, D. G., Holden, F. R., and Walton, J. D. 1993. Cloning and targeted gene disruption of $X Y L 1$, a $\beta 1,4$-xylanase gene from the maize pathogen Cochliobolus carbonum. Mol. Plant-Microbe Interact. 6:467-473.

3. Apel-Birkhold, P. C., and Walton, J. D. 1996. Cloning, disruption, and expression to two endo- $\beta-1,4-x y l a n a s e$ genes, $x y l 2$ and $x y l 3$, from Cochliobolus carbonum. Appl. Environ. Microbiol. 62:4129-4135.

4. Ausubel, F. M., Brent, R., Kingston, R. E., Moore, D. D., Seidmann, J. G., Smith, J. A., and Struhl, K. 1987. Current Protocols in Molecular Biology. John Wiley \& Sons, New York.

5. Bradford, M. M. 1976. A rapid and sensitive method for the quantitation of microgram quantities of protein utilizing the principle of protein dye binding. Anal. Biochem. 72:248-254.

6. Brockmann, B., Smit, R., and Tudzynski, P. 1992. Characterization of an extracellular $\beta$-1,3-glucanase of Claviceps purpurea. Physiol. Mol. Plant Pathol. 40:191-201.

7. Caddick, M. X. 1992. Characterization of a major Aspergillus regulatory gene, areA. Pages 141-152 in: Molecular Biology of Filamentous Fungi. U. Stahl and P. Tudzynski, eds. VCH Verlagsgesellschaft $\mathrm{mbH}$, Weinheim, Germany.

8. Carpita, N. C., and Gibeaut, D. M. 1993. Structural models of primary cell walls in flowering plants: Consistency of molecular structure with the physical properties of the walls during growth. Plant J. 3:1-30.

9. Cenis, J. L. 1992. Rapid extraction of fungal DNA for PCR amplification. Nucleic Acids Res. 20:2380.

10. Chambers, A. A., and Russo, V. E. A. 1986. Isolating RNA is easy and fun. Fungal Genet. Newslett. 33:22-23.

11. Cubero, B., and Scazzocchio, C. 1994. Two different, adjacent and devergent zinc finger binding sites are necessary for CREA-mediated carbon catabolite repression in the proline gene cluster of Aspergillus nidulans. EMBO (Eur. Mol. Biol. Organ.) J. 13:407-415.

12. Dalboege, H., and Heldt-Hansen, H. P. H. 1994. A novel method for efficient expression cloning of fungal enzyme genes. Mol. Gen. Genet. 243:253-260.

13. Düvell, A., Hessberg-Stutzke, H., Oeser, B., Rogmann-Backwinkel, R., and Tudzynski, P. 1986. Structural and functional analysis of mitochondrial plasmids in Claviceps purpurea. Mol. Gen. Genet. 214:128-134.

14. Esser, K., and Tudzynski, P. 1978. Genetics of the ergot fungus Claviceps purpurea. I. Proof of monoecious life cycle and segregation patterns for mycelial morphology and alkaloid production. Theor. Appl. Genet. 53:145-149.

15. Garre, V., Müller, U., and Tudzynski, P. 1998. Cloning, characterization and targeted disruption of cpcat1, coding for an in planta secreted catalase of Claviceps purpurea. Mol. Plant-Microbe Interact. 11:772-783.

16. Gilkes, N. R., Henrissat, B., Kilburn, D. G., Miller, R. C., Warren, R. C., Jr., and Warren, R. A. J. 1991. Domains in microbial $\beta$-1,4-glycanases: Sequence conservation, function, and enzyme families. Microbiol. Rev. 55:303-315.

17. Haas, H., Friedlin, E., Stöffler, G., and Redl, B. 1993. Cloning and structural organization of a xylanase-encoding gene from Penicillium chrysogenum. Gene 126:237-242.

18. Hanahan, D. 1983. Studies on transformation of Escherichia coli with plasmids. J. Mol. Biol. 166:557-563.

19. Handley, D. A. 1989. Methods for synthesis of colloidal gold. Pages 1332 in: Colloidal Gold: Principles, Methods, and Applications. Vol. 1. M. A. Hayat, ed. Academic Press, Inc., San Diego, CA.

20. Ito, K., Ikemasu, T., and Ishikawa, T. 1992. Cloning and sequencing of the xynA gene encoding xylanase A of Aspergillus kawachii. Biosci. Biotech. Biochem. 56:906-912.

21. Ko, E. P., Akatsuka, H., Moriyama, H., Shinmyo, A., Hata, Y., Katsube, Y., Rabe, I., and Okada, H. 1992. Site-directed mutagenesis at aspartate and glutamate residues of xylanase from Bacillus pumilus. Biochem. J. 288:117-121.

22. Kombrink, E., Schröder, M., and Hahlbrock, K. 1988. Several "pathogenesisrelated" proteins in potato are $\beta$-1,3-glucanases and chitinases. Proc. Natl. Acad. Sci. U.S.A. 85:782-786.

23. Kurzátkowski, W., Solecka, J., Filipek, J., Rozbicka, B., Messner, R., and Kubicek, C. P. 1993. Ultrastructural localization of cellular compartments involved in secretion of the low molecular weight alkaline xylanase by Trichoderma reesei. Arch. Microbiol. 62:2859-2865.

24. Lämmli, U. K. 1970. Cleavage of structural proteins during the assembly of the head of bacteriophage T4. Nature (Lond.) 227:680-685.

25. Mach, R. L., Strauss, J., Zeilinger, S., Schindler, M., and Kubick, C. P. 1996. Carbon catabolite repression of xylanase I (xynl) gene expression in Trichoderma reesei. Mol. Microbiol. 21:1273-1281.

26. Mantle, P. G., and Nisbet, L. J. 1976. Differentiation of Claviceps purpurea in axenic culture. J. Gen. Microbiol. 93:321-334.

27. Müller, U. 1997. Struktur, Expression und gezielte Inaktivierung von cell, einem vermutlich Cellobiohydrolase-codierenden Gen von Claviceps purpurea. Bibl. Mycol. 166:1-100.

28. Müller, U., Tenberge, K. B., Oeser, B., and Tudzynski, P. 1997. Cel1, probably encoding a cellobiohydrolase lacking the substrate binding domain, is expressed in the initial phase of Claviceps purpurea on Secale cereale. Mol. Plant-Microbe Interact. 10:268-279.

29. Murphy, J. F., and Kyle, M. M. 1995. Alleviation of restricted systemic spread of pepper mottle potyvirus in Capsicum annuиm cv. Avelar by coinfection with a cucumovirus. Phytopathology 85:561-566.

30. Sambrook, J., Fritsch, E. F., and Maniatis, T. 1989. Molecular Cloning: A Laboratory Manual, 2nd ed. Cold Spring Harbor Laboratory Press, Cold Spring Harbor, NY.

31. Shaw, S., and Mantle, P. G. 1980. Host infection by Claviceps purpurea. Trans. Br. Mycol. Soc. 75:77-90.

32. Sheppard, P. O., Grant, F. J., Oort, P. J., Sprecher, C. A., Foster, D. C., Hagen, F. S., Upshall, A., Mcknight, G. L., and O'Hara, P. J. 1994. The use of conserved cellulase family-specific sequences to clone the cellulase homologue cDNAs from Fusarium oxysporum. Gene 150:163-167.

33. Short, J. M., Fernandez, J. M., Sorge, J. A., and Huse, W. D. 1988. Lambda ZAP: A bacteriophage lambda expression vector with in vivo excision properties. Nucleic Acids Res. 16:7583-7600.

34. Smit, R., and Tudzynski, P. 1992. Efficient transformation of Claviceps purpurea using pyrimidine auxotrophic mutants cloning of the OMP decarboxylase gene. Mol. Gen. Genet. 234:297-305.

35. Tenberge, K. B. 1992. Ultrastructure and development of the outer epidermal wall of spruce (Picea abies) needles. Can. J. Bot. 70:1467-1487.

36. Tenberge, K. B., and Eising, R. 1995. Immunogold labelling indicates high catalase concentrations in amorphous and crystalline inclusions of sunflower (Helianthus annuus L.) peroxisomes. Histochem. J. 27:184-195.

37. Tenberge, K. B., Homann, V., Oeser, B., and Tudzynski, P. 1996. Structure and expression of two polygalacturonase genes of Claviceps purpurea oriented in tandem and cytological evidence for pectinolytic enzyme activity during infection of rye. Phytopathology 86:1084-1097.

38. Tilburn, J., Sarkar, S., Widdick, D. A., Espeso, E. A., Orejas, M., Mungroo, J., Penalva, M. A., and Arst, H. N. 1995. The Aspergillus PacC zinc finger transcription factor mediates regulation of both acid- and alkaline-expressed genes by ambient pH. EMBO (Eur. Mol. Biol. Organ.) J. 14:779-790.

39. Törrönen, A., Mach, R. L., Messner, R., Gonzalez, R., Kalkkinen, N., Harkki, A., and Kubicek, C. P. 1992. The two major xylanases from Trichoderma reesei. Bio/Technology 10:1461-1465.

40. Tudzynski, P., Tenberge, K. B., and Oeser, B. 1995. Claviceps purpurea. Pages 161-187 in: Pathogenesis and Host Specificity in Plant Diseases: Histopathological, Biochemical, Genetic and Molecular Bases. Vol. II. Eukaryotes. K. Kohmoto, U. S. Singh, and R. P. Singh, eds. Pergamon Press, Elsevier Science, Oxford.

41. Tudzynski, P., and Tudzynski, B. 1997. Genetics of plant pathogenic fungi. Pages 169-193 in: Progress in Botany, Vol. 59. Springer Verlag, Berlin.

42. van Ooyen, A. J. J., de Graaff, L. H., van den Broek, H. C., and Visser, J. 1994. Cloning and expression xylanase B. In: International Patent Application WO04/14965, Gist-Brocades, Delft, the Netherlands.

43. Varner, J. E., and Ye, Z. H. 1994. Tissue printing. FASEB (Fed. Am. Soc. Exp. Biol.) J. 8:378-384.

44. Wakarchuk, W. W., Campbell, R. L., Sung, W. L., Davoodi, J., and Yaguchi, M. 1994. Mutational and crystallographic analyses of the active site residues of the Bacillus circulans xylanase. Protein Sci. 3:467-475.

45. Wood, W. B. 1966. Host specificity of DNA produced by Escherichia coli: Bacterial mutation affecting the restriction and modification of DNA. J. Mol. Biol. 16:118-133.

46. Wu, S.-C., Kauffmann, S., Darvill, A. G., and Alversheim, P. 1995. Purification, cloning and characterization of two xylanases from Magnaporthe grisea, the rice blast fungus. Mol. Plant-Microbe Interact. 8:506-514.

47. Yaguchi, M., Roy, C., Watson, D. C., Rollin, F., Tan, L. U. L., Senior, D. J., and Saddler, N. 1992. The amino acid sequence of the 20kd xylanase from Trichoderma harzianum E58. Pages 435-438 in: Xylans and Xylanases. J. Visser, G. Beldman, M. A. Kuster-van Someren, and A. G. J. Voragen, eds. Elsevier, Amsterdam.

48. Yanisch-Perron, C., Vieira, J., and Messing, J. 1985. Improved M13 phage cloning vectors and host strains: Nucleotide sequence of the M13 mp18 and pUC19 vectors. Gene 33:103-109. 